\title{
Pollyannas, Pessimists, and the Science of Happiness
}

Jared K. Rothstein, Ph.D.

Professor and Lead Instructor of Philosophy, School of Behavioral and Social Sciences, Daytona State College, United States.

Article Details
Article Type: Research Article
Received date: $07^{\text {th }}$ June, 2021
Accepted date: $12^{\text {th }}$ July, 2021
Published date: $14^{\text {th }}$ July, 2021

"Corresponding Author: Jared K. Rothstein, Ph.D.., Professor and Lead Instructor of Philosophy, School of Behavioral and Social Sciences, Daytona State College, United States. E-mail: Jared.Rothstein@,daytonastate.edu

Citation: Rothstein, J.K. (2021). Pollyannas, Pessimists, and the Science of Happiness. J Ment Health Soc Behav 3(2):144. https://doi.org/10.33790/jmhsb1100144

Copyright: (C2021, This is an open-access article distributed under the terms of the Creative Commons Attribution License $\underline{4.0}$, which permits unrestricted use, distribution, and reproduction in any medium, provided the original author and source are credited.

\begin{abstract}
With personal anecdotes, the author contrasts his natural pessimism with the outlook of his mother, a lifelong Pollyanna, and investigates the source of this core difference. He argues that, despite its scientific veracity and likely implications that nothing is cosmically 'meant to be,' Darwin's theory of natural selection neither conclusively resolves metaphysical debates concerning the existence of god nor the existential question of which life perspective is most appropriate. Furthermore, based on interdisciplinary research from the field of positive psychology, the author rejects Jean-Paul Sartre's alternative suggestion that we are either optimistic or cynical solely by choice. Contrary to Sartre's 'blank slate' conception, these empirical findings indicate that a person's baseline happiness level and natural outlook on life is genetically driven to a significant degree. While there is a 'cortical lottery' in this regard, environmental factors also play a key role---a scientific result that fits nicely with Aristotle's 'golden mean' theory of happiness.
\end{abstract}

\section{Introduction}

My mom raised me as a single parent from the time I was eight years old, largely in her own image. A PhD clinical psychologist, she served as the director of a child development and parenting clinic at McGill University during my infancy. As might be expected, she brought this expertise home. Throughout my childhood, I benefited from a dazzling array of intellectual games, mental stimulation exercises, and parenting techniques at the vanguard. My mother consistently modelled the virtues of curiosity, independence, industriousness, and self-confidence. As a strong feminist with little patience for traditional "male shortcomings," she insisted that I develop introspective awareness and a capacity to adequately communicate my feelings, thoughts, and desires. Moreover, in accord with her therapeutic orientation, a mix of cognitive-behaviorism and existential psychology, she taught me to assume personal responsibility for my actions and emotional well-being and the overarching importance of squarely facing 'reality.' Despite her enduring agnosticism and strong atheistic leanings, my mother nevertheless encouraged me to reach my own metaphysical conclusions. Alas, after lengthy philosophical explorations, the apple did not fall far from the tree in this regard. Indeed, at my current age of forty, one thing is clear: whether due more to nature or nurture, I am clearly my mother's son, a carbon copy in many respects except, that is, for one major difference.

Notwithstanding our many similarities and shared philosophical orientation, my mother is a lifelong Pollyanna, while I am anything but! For as long as I can remember, I have harbored generalized anxieties, pessimistic ruminations, and depressive tendencies, which are completely absent from her sanguine personality. While I have battled insomnia for years, my mom sleeps soundly, night after night. Whereas I worry about future calamities and see 'Murphy's law' everywhere in action, she remains buoyed by an irrepressible belief that "everything will work out as it should." Although I am readily burdened by guilt, she cannot recall ever personally experiencing this emotion. I have seen my mother depressed on occasion, typically due to monetary concerns and frustrations about an inability to ever retire, but these rare episodes have been justified by external realities and remarkably fleeting in general. True to her well-earned nickname, "Polly's" uncanny resiliency and hopefulness never ceases to amaze me. We have both followed Socrates' directive to lead an examined life, but alas, Robert Fulghum's response that "the examined life is no picnic" only seems to apply in my case.

Indeed, this stark disparity raises some interesting questions. To what degree are these fundamental orientations - the Pollyanna versus the Pessimist-hardwired personality types? Are these existential attitudes instead merely a matter of free choice, as Sartre claims? Does Darwin's theory of natural selection require the adoption of one outlook over another? In Section I, I argue that this biological account does not conclusively settle metaphysical debates concerning the existence of God, contrary to what some atheistic theorists have recently implied. Similarly, Darwin's theory is consistent with either an optimistic or a cynical view of life, as my mother and I aptly demonstrate. Our response is characteristically divergent in this respect although we both draw the same metaphysical implications from Darwin's view that likely nothing is 'meant to be.'

In Section II, I critique Jean-Paul Sartre's alternative suggestion that we can change our outlook on life at will. I contend that, by ignoring the importance of genetic inheritance, his 'blank slate' conception of the 'self' conflicts with empirical findings from the interdisciplinary field of positive psychology. As highlighted in the last section of this paper, this research indicates that there is a cortical lottery for happiness and optimism [1]. Some fortunate individuals, like my mother, are naturally disposed in this manner; while others, like me, have the opposite inclination. While these personality characteristics are highly heritable and tend to persist over time, environmental variables are also important; and it would therefore be wrong to conclude that we are genetically determined with respect to these traits [1]. This dynamic interplay between internal and external factors is discussed in connection with Aristotle's [2] "golden mean" theory of happiness, which accords nicely with the science.

\section{Meant to Be?}

Pollyanna that she is, my mother typically responds to life tribulations with the same jovial mantra, one that never fails to elicit an eye 
roll from me. "Well, I guess it was just meant to be," she will confidently proclaim. Another of her son's romantic disappointments? "Meant to be!" Job market frustrations? "Meant to be!" Major household repair? You get the idea. Natural pessimism aside, what drives me especially crazy about this response is that I know she does not mean it, at least in any conventional sense of the expression. Typically, those who espouse a view that events are 'meant to be' are thinking in terms of fate, conceived as some sort of preordained plan (e.g., "God's will") or inexorable destiny (e.g., "you are my soulmate, and we were fated to be together"). Such fatalistic views have a long history. The tension between destiny and volitional choice was a major preoccupation of the Ancient Greek mind, as reflected in their literature and philosophy [3]. Around the Fifth Century BC, for example, the first atomist, a Pre-Socratic philosopher named Democritus, claimed that all things come to pass "by necessity" in a world governed by fixed causal laws and completely devoid of randomness [4]. Notwithstanding Democritus' unique approach, which does not reference any divinity, Ancient Greek conceptions of fate typically revolved around the will of the gods - and to this day, views of divine preordination persist among the religiously devout [3].

Surely, my mother does not believe anything of this sort. While self-identifying as an agnostic, since "we can never be absolutely certain regarding such matters," she is as fervently atheistic as anyone I have known. In her over fifty years of clinical experience, she has observed a strong correlation between various types of mental illness and religious zealotry-a subject which, as it happens, has been the focus of exciting new cognitive scientific research [5]. My mother understands the psychological allure of religious belief as a coping mechanism for loss and disappointment. There is, however, in her view, no epistemic justification for adopting such an "unscientific" worldview. She has zero patience for those who would deign to proselytize to her and no compunction about telling them so; as I witnessed throughout my childhood anytime some unwitting stranger rang the doorbell to "spread the good word" before quickly realizing that this was the wrong house! Indeed, far from believing in fate or preordination of any kind, my mother has always espoused the opposite view that there is no grand teleological plan nor purpose for our existence, no godhead personally invested in our lives. On the contrary, blind chance is the operative principle in this godless universe, and nothing is cosmically 'meant to be.' From her perspective, this metaphysical viewpoint follows naturally from Darwin's account of natural selection [6].

Many theorists [7-9], including me, have drawn similar conclusions, although the metaphysical implications of this watershed scientific discovery are open to interpretation [10]. Darwin's biological theory addresses an age-old question that has preoccupied thinkers for millennia: what is the origin of species, including human beings? Prior to Darwin, the consensus view held that species were simply 'meant to be' - an inextricable part of the grand design of nature [4]. In the Fourth Century BC, despite his precocity as a dedicated biologist, Aristotle notoriously claimed that species could not go extinct [4]. Like his predecessor, Plato, Aristotle believed in a purposeful and harmonious universe in which each known species has an essential and timeless role to play [4]. In accord, religious believers, both prior and following, have long credited the gods with designing the variegated species populating our planet; albeit, typically with a special place carved out for humans as the supposed pinnacle of creation, closest in form to divinity.

Darwin's theory, in contrast, provides a 'bottom up' account of speciation, predicated on random genetic mutation in combination with environmental selection pressures. As the evolutionary biologist Richard Dawkins [6] aptly describes in The Selfish Gene, the best way to think about natural selection is in terms of replicating genes, copied from one generation to the next. Genes carry DNA, which determine the hereditary traits (physical and mental) of an individual organism. Within any given environment, some traits will be more adaptive than others; and better suited individuals will, in turn, be more likely to survive, reproduce, and pass on these successful genes to their offspring [6]. Through the course of this reproductive process, however, chance genetic mutations occur, resulting in new hereditary traits; some of which may confer enhanced fitness and thus spread in frequency through subsequent generations. In this way, Darwin explains how species gradually evolve and potentially go extinct and how in this manner primordial microbes can slowly transmogrify and scale up into vastly more complex organisms, like homo sapiens [6]. Here we have a radically different account of origins as compared to the Platonic/Religious tradition. Based on the theory of natural selection, it appears that no species are 'meant to be' in the archaic sense. Darwin's view implies, on the contrary, that all species are here accidentally, based solely on random mutations and serendipitous environmental forces and are subject to extinction on the same tenuous basis. Far from destined, animal existence is ostensibly just a matter of haphazard luck and contingency.

Today, there is no question regarding the scientific veracity of Darwin's theory of natural selection; based on overwhelming evidence from a wide swath of empirical disciplines, including the field of advanced genetics [6]. The metaphysical and existential implications of Darwin's breakthrough, however, remain controversial: an important distinction that has unfortunately been muddled by some overzealous atheistic writers, like Richard Dawkins [7] and Christopher Hitchens [8], who have argued that this biological theory conclusively settles the religious debate. For example, in his book God is not Great, Hitchens [8] contends that Darwin's view completely undercuts the famous 'design argument' for God's existence. Prior to Darwin, there was mystery surrounding the wondrous 'order' observable in our world, the striking way in which animals seem so well suited to their natural environments - as if it was 'meant to be,' i.e., the product of an intelligent designer. Hitchens stresses that this outmoded, 'top down' style argument, which posits something even more complex and confounding to explain nature's intricacies, entails a regress problem; since now we need to account for the origins of this 'higher being,' and so on and so forth. Darwin's 'bottom up' account of speciation, in contrast, avoids this difficulty while providing a much better explanation for these natural adaptations, without all the needless theological difficulties. On this basis, Hitchens asserts that the 'design argument' cannot withstand 'Ockham's razor,' a principle of theory adoption according to which, given competing explanations, we ought to select the simplest. He writes in summary,

- The postulate of a designer or creator on raises the unanswerable question of who designed the designer or created the creator. Religion and theology...have consistently failed to overcome this objection... Now that religion's monopoly has been broken, it is within the compass of any human being to see [them] as the feeble-minded inventions that they are (71).

Undoubtedly, there is tension between these 'bottom up' and 'top down' accounts, but notwithstanding Hitchens' screed, they can be reconciled: Darwinian evolution is not necessarily incompatible with the existence of God. One could claim, for example, that God set the evolutionary process in motion; echoing the position of Aristotle [11] who long ago postulated the existence of a creator god, an "unmoved mover," who was not otherwise involved in worldly affairs. Indeed, Ockham's razor can be a useful tool for adjudicating between competing scientific theories, but it can never definitively settle metaphysical disputes. It is possible, after all, that the ultimate truth concerning the origins of life is not the simplest possible explanation. The great empiricist David Hume (2013) famously concluded An Enquiry Concerning Human Understanding with a call to burn books 
of pure metaphysics, since questions of this sort cannot be resolved empirically. While Darwin's theory is scientifically unassailable, the metaphysical implications are inconclusive, contrary to what Hitchens suggests. I am more sympathetic with Hitchens' epistemological claim that Darwin's theory undermines any rational justification for believing in God, such that this can only be accepted on faith alone (which happens to be Ockham's position as well). Just because we do not have good reason for believing a metaphysical proposition, however, does not mean that it is necessarily false; and so, some degree of humility regarding such lofty questions is advisable. While Hitchens and Dawkins (2008) fall short in this regard, my mother better personifies this wisdom. As noted above, despite her appreciation for Darwin's theory and strong atheistic tendencies, she prudently acknowledges that one can never be certain regarding the existence of God.

In any case, the fundamental difference in general outlook between my mom and me does not stem from a divergence in metaphysical worldview. As it turns out, we share the same Darwinian view of nature and working hypothesis that there is no preordained script nor plan for human existence in this apparently godless universe. Darwin's scientific theory, however, does not definitively settle questions concerning God's existence, nor does it necessitate one existential attitude over another, as my mother and I aptly demonstrate. We both believe that nothing is 'meant to be' in the traditional sense of the phrase, but while I tend to find this depressing, my mother focuses on the positive, as usual. Whereas I bemoan the indignities and burdens of biological existence - e.g., the ineluctability of sickness, death, etc. - she celebrates the serendipitous events in life, including being born in the first place. Empirical findings from the field of positive psychology reveal a strong correlation between one's life outlook and baseline happiness level over time [1]. Unsurprisingly, optimists are generally happier than pessimists [1]; and my mother and I are no exception. Indeed, her nonconventional usage of the 'meant to be' idiom, which always vexes me, is best understood as an expression of her indomitable optimism and existentialist orientation. In her view, individuals are ultimately responsible for generating their own meaning and purpose in life and for turning apparent failures and disappointments into opportunities for growth and improvement: life events are 'meant to be' in this sense solely because we deem them so. Are existential attitudes, then, solely a matter of will too? JeanPaul Sartre [12], the famed existentialist philosopher, subscribed to this controversial view.

\section{The Sartrean 'Blank Slate'}

Notwithstanding our shared philosophical orientation, my mother remains a consummate Pollyanna in contrast to me, the perennial cynic. So, the mystery remains, what accounts for this discrepancy? Another possible explanation is provided by Sartre, who similarly believed that nothing is 'meant to be.' Like Nietzsche [13] before him, and eschewing the caution recommended in the previous section, Sartre [14] categorically proclaimed that "God is dead;" a somewhat misleading headline since neither of these atheists thought that God ever lived in the first place. Both, however, detected that a profound cultural shift was underway. They believed that with modern advances, scientific and otherwise, religion was quickly losing its hold on the popular imagination, dying as it were [15]. This was a most welcome development for Sartre, who championed freedom and self-determination as the preeminent values in human life [16]. In his analysis, if nothing is 'meant to be,' then individuals are free to create their own meaning and purpose, without any externally imposed script or blueprint. He claims that, unlike all other things in existence, such as a rock or a table, human beings do not have a fixed essence or nature. Rather, we are defined solely by our choices. The actions we take determine who we are, and we can always recreate ourselves, accordingly.

J Ment Health Soc Behav

Volume 3. 2021. 144
With his message of freedom and rejection of conventional authority, Sartre found a natural audience among the 'turn on, tune in, drop out' crowd of the 1960s, a group which included my mother. His philosophy and its extension to the field of existential psychology, as exemplified by the writings of Victor Frank1 [17] and Rollo May [18], would have an enduring impact on her clinical orientation and practice throughout her long career. My mother has always liked existential psychology's emphasis on healthy self-narratives and on assuming personal accountability for our choices and happiness. According to this therapeutic approach, how we conceive of ourselves and the significance we impute to our experiences colors our world; and by examining our habitual thought patterns and behaviors and making any necessary changes, we can enhance and transform our existence (May 2000). Most vitally, we must infuse our lives with purpose to satisfy an inherent need. Frankl [17] stresses that an individual's "search for meaning is the primary motivation in [his or her] life... This meaning is unique and specific in that it must and can be fulfilled by the [individual] alone" (105). This tends to be an easier achievement for natural optimists like my mother. For my fellow cynics, on the other hand, finding meaning in adversity can be more challenging, which is one of the reasons why existentialism's focus on this topic has resonated with me so deeply over the years.

As an anxiety-prone individual with perfectionistic tendencies, I have connected with Sartre's philosophy in this respect too. He underscores that our radical freedom for self-determination comes at a cost. In typically provocative fashion, he (2007) remarks in his Existentialism Is A Humanism lecture that "we are condemned to be free." Why "condemned?" Sartre emphasizes that liberty entails anxiety - the burden of choice--which he refers to as existential angst. Freedom carries the responsibility to choose wisely; and as options increase, it can become increasingly difficult to decide among them and to be happy with the eventual choice. I often have this experience shopping at the grocery store, where, for example, trying to choose between innumerable varieties of toothpaste can present a real challenge. On such occasions, I wish that there were less options at my disposal to facilitate my decision and to forestall the inevitable second-guessing once I get home. Online shopping platforms, like Amazon, with their seemingly endless profusion of goods from which to choose, can be a nightmare in this regard. Characterizing this 'paradox of choice,' the eminent psychologist Jonathon Haidt [1] writes, "we value choice and put ourselves in situations of choice, even though choice often undercuts happiness" (102). As counterintuitive as it may seem, having more alternatives can cause greater stress; especially for people predisposed to depression and anxiety (Haidt, 102). This pressure is not just limited to perfectionists, however. In Nichomachean Ethics, Aristotle [2] famously observes that every choice an individual makes is ultimately aimed at facilitating happiness, as this person's end goal. Similarly, the Nobel Prize winning behavioral economist Richard Thaler [19] emphasizes that, although we often fall short, rational agents are naturally motivated to make 'optimal' choices, i.e., to pick the one option among alternatives that would maximize preference satisfaction. Hence, the 'paradox of choice' applies to everybody. Sartre, to his credit, fully grasps the universality of this challenge; and particularly as it pertains to higher-stake life decisions, which tend to be even more angst-ridden. Should I change my career path? Give up my bachelor lifestyle and settle down, or not? Buy that new car? Frequently in these situations, as the number of options grow, so too does the decision-making burden.

Well, then, what ought we to do? Alas, Sartre is not very helpful in this regard. He implores us to make 'authentic' choices in the face of existential angst, but he offers no specific guidance. At the end of Being and Nothingness, he [12] notoriously defines 'authenticity' in the most obscure terms imaginable, writing, "a freedom which wills 
itself freedom is in fact a being-which-is-not-what-it-is and whichis-what-it-is-not" (798). Unwitting parody aside, Sartre indicates that most people fall short of this vague ideal. In a key section entitled "Bad Faith" from this same book, he at least presents a clearer picture of its antithesis, inauthentic living, which he characterizes as a "lie to oneself" (87). He suggests that 'bad faith' involves a mistaken selfconception. To escape the burden of choice, individuals deny their own liberty by misattributing to themselves a fixed essence or nature, which they believe they are powerless to overcome [20]. Typically, this falsehood unduly reflects the perceptions and expectations of others - a hazard to which Sartre [21] famously refers at the end of his play No Exit ("hell is other people"). Aside from these general admonitions, however, he provides no concrete guidance for how to live authentically, which is perhaps inevitable given his problematic view of the 'self.'

Sartre urges paradoxically, 'be true to yourself,' while simultaneously maintaining that the 'self' is completely fluid-fundamentally, nothing--a theme which he develops in Being and Nothingness [12] as well as an in an earlier work, The Transcendence of the Ego (1991). In both texts, Sartre stresses that our unique form of consciousness serves primarily as an alienating force, separating us from the rest of the world. For example, in perceiving this table, I am also aware of it as 'not me.' If I try, in contrast, to turn my attention inward and observe my 'true self,' I am bound to come up empty; since 'I' am not like a table or any other 'object' of consciousness, but rather something far more elusive and ephemeral. Based on this kind of introspective exercise, David Hume [22] famously defined the 'self' as just a "bundle of perceptions," without a perceptible hub. Similarly, Sartre concludes that we are merely fleeting whisps of nothingness. And herein lies the problem: within this theoretical framework, what could it possibly mean to live authentically? How can I genuinely be nothing? Sartre dismisses all the conventional anchors of self-identity--who we have been in the past, what we might view as our inherent nature or personality, our social roles and obligations - leaving only a gaping void.

Is it any wonder, then, why a Sartrean would be so angst-ridden? He argues that you are radically free, with endless life possibilities from which to choose. This burden is yours alone to bare, and the decisions you make going forward will define who you are. Your past is irrelevant, as are the wishes of others, and there is no core to your personality. You must remain ever vigilant, however, and never act in 'bad faith,' an impossible standard to meet when you can never be sure about what constitutes your authentic 'self.' This is a perfect formula for limitless anxiety when you are naturally driven to make 'optimal' choices [19] and to achieve happiness [2]: dangling a tantalizing but evasive ideal, forever just out of reach. Perhaps this explains why Sartre's philosophy has always appealed to me as an angsty pessimist. He provides so much grist for the mill in this regard! In emphasizing our supposedly boundless freedom and vacuity, his philosophy supercharges the 'paradox of choice;' which only induces more stress. Moreover, there is the added pressure to adopt a better attitude, which Sartre argues is completely within our power as well. In his view, the general outlook on life we assume, like everything else we do, is freely chosen and without objective merit. As such, why not just adopt a rosier perspective?

Although Sartre intends this message to be liberating, it relies on an empirically implausible 'blank slate' conception of the 'self,' which ignores the fundamental role of genetic inheritance. Despite what he contends, my lifelong pessimism does not seem like just a passing whim, merely a matter of will. On the contrary, this disposition appears to be part of who I am, down to the core, and the same holds for my mother and her natural buoyancy. Sartre, of course, would dismiss this psychological claim as 'bad faith' on my part. According to him, I could transform into a Pollyanna instantly, with just the snap of a finger. Scientific findings from the field of positive psychology indicate otherwise. As a matter of fact, we are not so radically indeterminate and nebulous, after all. On the contrary, we possess enduring personality traits and tendencies, many of which are genetically hardwired to varying degrees. Among the most heritable of these characteristics is a person's natural inclination toward either optimism or cynicism and baseline happiness level over time. Environmental factors, however, play a significant role in determining how these heritable dispositions are expressed, and Sartre is thus right to reject claims of strong genetic determinism. Nonetheless, in failing to acknowledge the major importance of these inborn personality forces, his 'blank slate' view rings hollow. When it comes to an individual's outlook on life, there is a cortical lottery involved as well.

\section{The Cortical Lottery}

One of the greatest mysteries in life concerns the origins of personality. Are we shaped more by genes or environment? This nature/nurture debate has raged for millennia and remains unsettled to this day, although recent scientific findings have shed new light on this hoary controversy and refined its focus [23]. Historically, theorists have staked out one extreme position or the other. In philosophy, nativists, like Plato and Descartes, argued that we come equipped with a broad suite of innate ideas and capacities; while 'blank slate' theorists, such as John Locke, have contended just the opposite. Sartre's account falls into the latter category by ignoring the key role of hereditary traits. This anti-nativist stance also accords with the behaviorist movement in psychology, as championed by its founders J.B. Watson and B.F. Skinner [4]. In the 1960s, my mother received her doctorate in psychology from a leading behaviorist program, the University of Illinois at Champaign-Urbana. Despite this training, however, what has impressed my mother the most over her fifty plus years of clinical practice is the manifest importance of genetic inheritance, more so than environment, in many cases; although she acknowledges that there is almost always an interactive effect. Indeed, this interactionist view has risen to the fore in recent years, as the extremist positions mentioned above have fallen by the wayside [23]. Today, the chief scientific question is no longer whether genes or environment shape who we are-since both are clearly involved - but rather the degree to which one factor may be more significant than another for the expression of a particular trait [23]. Some personality characteristics are more heritable than others, including those most germane to our present study.

In his outstanding book The Happiness Hypothesis, Jonathan Haidt [1] underscores that one's general happiness level is among the most genetically driven traits. Consistent with my mother's clinical experience, he writes, "when it comes to explaining personality, it's always true that nature and nurture work together. But it's also true that nature plays a bigger role than most people realize" (32). This applies especially to a person's 'affective style,' i.e., the way one typically feels daily, which is how 'happiness' is operationally defined and measured within the field of positive psychology (Haidt, 33). Haidt reports, "twin studies generally show that from fifty to eighty percent of all the variance among people in their average levels of happiness can be explained by differences in their genes rather than in their life experiences" (33). It appears that some people are naturally happier than others, and while life events can cause temporary fluctuations, one's default affective style tends to persist over time. Haidt explains, "your affective style reflects the everyday balance of power between your approach and your withdrawal system, and this balance can be read right from your forehead" (33). People typically show more brainwave activity in either the left or the right frontal cortex, located behind the forehead, which is strongly correlated with affective style. 'Lefties' are generally happier and report less feelings of shame, anxiety, and fear than 'righties.' Members of the 
former group also tend to be less depression-prone and are quicker to bounce back from negative life events (Haidt, 33). These affective patterns emerge very early in development, with 'righty' babies as young as ten months old showing greater separation anxiety than their 'lefty' peers, and these emotional proclivities typically endure all the way through adulthood (Haidt, 33).

Unsurprisingly, affective style is strongly correlated with one's natural outlook on life. Haidt emphasizes, "optimists are, for the most part, people who won the cortical lottery. They have a high happiness setpoint, they habitually look on the bright side, and they easily find silver linings. Life has a way of making the rich get richer and the happy get happier" (146). Buoyed by a rosier viewpoint, cortical 'lefties' generally deal better with adversity and trauma, naturally adopting healthier coping strategies, such as reappraisal and proactive intervention. This, in turn, leads to better outcomes and more optimism. Alas, the poor also get poorer in this regard. Haidt writes, "people who have a relatively negative affective style (complete with more activity in the front right cortex than the left) live in a world filled with many more [perceived] threats and have less confidence that they can deal with them" (146). As a result of these negatively skewed perceptions, pessimists tend to adopt more maladaptive coping strategies, like avoidance, which triggers more cynicism, and so on and so forth. In this manner, a person's hardwired inclination can be a self-reinforcing phenomenon. This helps to explain why there is such a strong correlation between one's natural outlook and average happiness level, both of which closely track cortical dominance. We have on the one hand, 'lefties' disposed to happiness and optimism, and on the other, 'righties' prone to morosity and pessimism. My habitually upbeat mom is a paragon example of the former, while I am not so fortunate-which you would never predict considering our very different upbringings. While she was subjected to prolonged physical and mental abuse at the hands of her father, my childhood was filled with only love and support: demonstrating the resiliency of our divergent genetic tendencies. Speaking of which, given the high heritability of these traits, any guesses regarding into which group my dad falls? Let's just say, in this respect, I am a chip off the paternal block!

While these scientific findings are illuminating, they should not be exaggerated. Even with genetically driven traits like these, environmental forces still play a vital role, leaving ample room for individual variation. Haidt underscores,

- yes, genes explain for more about us than anyone had realized, but the genes themselves often turn out to be sensitive to environmental conditions. And yes, each person has a characteristic level of happiness, but it now looks as though it is not so much a set point as a potential range or probability distribution. Whether you operate on the high or the low side of your potential range is determined by many [external] factors... (90).

Regarding these external factors, empirical findings from positive psychology indicate that close relationships and meaningful work are among the most important for achieving happiness (Haidt, 219-223). In general, we need love and social support from others and engagement in a career pursuit that is personally fulfilling, rather than just a 'means to a paycheck'. Interestingly, the relationship between happiness and money is more nuanced (Haidt, 88-89). Predictably, people low in socioeconomic status who are struggling to meet basic survival needs tend to be less content than others who do not have these worries. Beyond this bottom threshold, however, there is a weaker correlation between happiness and affluence level. Haidt notes, "the rich are happier on average than the middle class but only by a little" (89). Despite these caveats, money remains another significant external factor; especially in my mother's opinion, for whom this is unquestionably the most salient consideration. Regardless, given the impact of all these outside variables, it is evident that we are not genetically determined to be happy or unhappy, optimistic or cynical. We are, however, naturally disposed toward one side of the spectrum or the other. In this sense, there is a cortical lottery, which is important to recognize: contra Sartre's contention, we are not 'blank slates,' after all.

Aristotle's [2] 'golden mean' theory of happiness, on the other hand, accords nicely with these empirical findings. He argues that leading a balanced life, encompassing both internal virtues and external goods, like friendship, is the key. Haidt draws the same conclusion at the end of his book, writing, "the final version of the happiness hypothesis is that happiness comes from between...Some of [the] conditions are within you... Other conditions require relationships to things beyond you" (238-239). With respect to internal factors, Aristotle again emphasizes balance and the 'middle way.' He sagely observes that, for any personality trait, the path to contentment lies somewhere in between either extreme. For example, take the virtue of 'honesty.' We can either be too blunt or not forthcoming enough, both of which miss the mark. Although the precise target can shift from one situation to the next, some of which might require more honesty than others, hitting the 'golden mean' bullseye requires a measured aim, centrally focused. The same dictum applies to every personality characteristic, according to Aristotle, which would include the trait of optimism. As discussed above, excessive cynicism can lead to depression and bad outcomes. Conversely, while optimism seems more conducive to happiness in general, this disposition in the extreme can also be deleterious, potentially leading to a lack of reality focus, etc. Hence, while speaking in terms of a cortical lottery for this trait makes sense, 'winning' the ultimate prize of happiness requires more than just genetic inheritance. Irrespective of neural inclination, achieving a 'golden mean' requires the right balance of internal and external factors.

Without a doubt, my mother has been the most significant outside force in my life, providing the perfect counterbalance to my overly pessimistic nature. I have always been able to count on her as my best friend and most trusted advisor and pro bono psychologist to point out cognitive distortions and to help me see the bright side. On innumerable occasions, she has told me to "stop ruminating and being so negative," while marveling at my seemingly boundless capacity for incessant worry, a tendency so foreign to her own constitutional makeup. For instance, when I suffered from a crippling bout of insomnia and writer's block as I scrambled to complete a last-minute essay on existentialism for graduate school admission, she was there for me. Subsequently, during my last year of graduate school, as I was despairing from a string of disappointments in a cutthroat job market, my mother provided the necessary support and encouragement. Throughout my life, time and time again at the most pivotal moments, her voice of calm and sanguinity was just what I needed to hear. She has also been a great example of how optimists tend to take proactive measures in the face of adversity. Rather than dwelling on a depressing circumstance, she focuses on finding a solution and making the required course correction, and then feels instantly better. Based in no small measure on her influence, currently I am much more adept at recognizing and counteracting the intrusive negative thoughts with which I have had a lifelong battle. Daily vigorous exercise has also been a great elixir for me, elevating my mood and transforming my natural affective style. Sometimes, much to my bemusement, I will even catch myself thinking, "it was just meant to be." While I will never be a Pollyanna like my mom, today I am closer to the 'golden mean' and happier than I have ever been: a testament to the malleability of genetic inheritance, even for 'losers' of the cortical lottery like me.

Indeed, learning about the science of happiness can have a profoundly 
liberating effect. For years, I wondered why my mother and I had such a different outlook on life despite so many other similarities. I knew this was not due to a divergent worldview, since we both draw the same basic conclusion from Darwinian evolution-i.e., that likely nothing is 'meant to be'-while also acknowledging that one could never have certitude regarding metaphysical questions of this sort. Contrary to what some atheistic theorists have suggested, Darwin's brilliant scientific discovery does not definitively settle disputes regarding the existence of God, let alone the existential question of whether optimism or cynicism is the most appropriate response. In arguing that these outlooks are merely a matter of will, which can be dispensed with at any time, Sartre's philosophy has always held provocative appeal for me. Maybe I am just a pessimist by choice? While Sartre intends this message to be freeing, it had the opposite effect on me, only increasing my natural anxiety. His fundamental error, it turns out, is his 'blank slate' conception of 'the self' and ignorance of the cortical lottery for happiness and optimism. Finally, a suitable explanation for the profound divergence between my mom and me regarding these characteristics! Fortunately, these neural tendencies are not inviolable, representing a range of possibility rather than a genetically determined setpoint. As with most heritable traits, external factors also play a large role. No theory of happiness, to my awareness, fits these findings better than Aristotle's 'golden mean' theory. While I wish all pessimists could have a Pollyanna in their life to facilitate this healthy balance, I believe understanding the science of happiness brings its own benefits in this regard. As it happens, there are many important lotteries in life, and I am most grateful personally for having hit the maternal jackpot!

Conflict of interests: The authors declare no conflict of interest.

\section{References}

1. Haidt, Jonathan. (2006). The Happiness Hypothesis: Finding Modern Truth in Ancient Wisdom. New York City: Basic Books.

2. Aristotle, Second Edition. (2014). Nicomachean Ethics. Edited by Roger Crisp. Cambridge: Cambridge UP.

3. Allen, Reginald E., ed., Third Edition, 1991. Greek Philosophy: Thales to Aristotle. New York City: The Free Press.

4. Miller Ed., and Jon Jensen, Sixth Edition. (2009). Questions that Matter: An Invitation to Philosophy. New York City: McGraw Hill.

5. McCauley, Robert N., and George Graham. (2020). Hearing Voices and Other Matters of the Mind: What Mental Abnormalities Can TeachUsAboutReligions. Oxford: OxfordUP.

6. Dawkins, Richard, Fourth Edition. (2016). The Selfish Gene. Oxford: Oxford UP.

7. Dawkins, Richard. (2008). The God Delusion. Boston: Mariner Press.

8. Hitchens, Christopher. (2007). God is Not Great: How Religion Poisons Everything. New York City: Hatchette Books.

9. Dennett, Daniel, Reprint Edition. (2007). Breaking the Spell: Religion as a Natural Phenomenon. London: Penguin Books.

10. Ruse, Michael. (2012). The Philosophy of Human Evolution. Cambridge: Cambridge UP.

11. Aristotle, Volume Two. (1995). "The Metaphysics." In The Complete Works. Edited by Jonathan Barnes. Princeton: Princeton UP.

12. Sartre, Jean-Paul. (1984). Being and Nothingness. Translated by Hazel Barnes.Washington D.C.: Washington Square Press.

13. Nietzsche, Friedrich.(1995). Thus Spoke Zarathustra. Translated by Walter Kaufmann. New York City: Modern Library.

14. Sartre, Jean-Paul. 2017. "A New Mystic.” In Critical Essays. Translated by Chris Turner. London: Seagull Books.
15. Barrett, William. (1990). Irrational Man: A Study in Existential Philosophy. New York City: Anchor Books.

16. Palmer, Donald, Eighth Edition. (2021). Does the Center Hold: An Introduction to Western Philosophy. New York City: McGraw Hill.

17. Frankl, Victor. (1984). Man's Search for Meaning. New York City: Simon and Schuster.

18. May, Rollo. (2009). Man's Search for Himself. New York City: W.W.Norton \& Company.

19. Thaler, Richard. (2015). Misbehaving, The Making of Behavioral Economics. New York: W.W. Norton and Company.

20. Sartre, Jean-Paul. (2007). Existentialism is a Humanism. Translated by Carol Macomber. New Haven: Yale University Press.

21. Sartre, Jean-Paul. (1955). No Exit and Three Other Plays. Translated by Stuart Gilbert. New York City: Vintage Books.

22. Hume, David. (2000). A Treatise of Human Nature. Edited by David Fate Norton and Mary J. Norton, Cambridge: Cambridge UP.

23. Sapolsky, Robert M. (2018). Behave: The Biology of Humans at Our Best and Worst. London: Penguin Books. 